\title{
Experimental and Numerical Analysis of the Punching Shear Resistance Strengthening of Concrete Flat Plates by Steel Collars
}

\author{
Ahmed Aziz Abdulhussein \\ Department of Civil Engineering \\ University of Baghdad \\ Baghdad, Iraq \\ a.abdhussain1101@coeng.uobaghdad.edu.iq
}

\author{
Mohannad H. Al-Sherrawi \\ Department of Civil Engineering \\ University of Baghdad \\ Baghdad, Iraq \\ Dr.Mohannad.Al-Sherrawi@coeng.uobaghdad.edu.iq
}

\begin{abstract}
In this study, six square reinforced concrete flat plates with dimensions of $(1500 \times 1500 \times 100) \mathrm{mm}$ were tested under a concentrated load applied on a column located at the center of the slabs. One of these slabs was the control specimen, whereas, in the others, steel angles (steel collars) were used, fixed at the connection region between the slab and the column to investigate the effect of the presence of these collars on punching shear strength. Five thicknesses were used $(4,5,6,8,10 \mathrm{~mm})$ with constant legs of angles $(75 \times 75) \mathrm{mm}$ of the steel collars to investigate the effects on the punching shear resistance with respect to the control slab. The results of the experimental study show that the punching shear resistance increased by 41 to $77 \%$ when steel collars were used. The experimental results were in good agreement with the numerical analysis acquired with the ABAQUS software.
\end{abstract}

Keywords-flat plates; punching shear strength; steel collar; strengthening

\section{INTRODUCTION}

Through the past decades, many experimental tests have been performed to enhance the punching shear strength of Reinforced Concrete (RC) flat plates by using different mechanisms and materials such as Carbon Fiber Reinforced Polymer (CFRP), shear bolts, shear reinforcements, and steel plates, placed in the slab around the column. Authors in [1] studied the strengthening of slab-column connection by drilling prestressed shear bolts in the slab regions around the columns. These bolts have high tensile strength with steel plates at each end. The experimental results showed that the ultimate load increased by about $67 \%$ with respect to the unbolted slab and the ultimate moment increased by $23 \%$ in comparison with the unbolted slab. Authors in [2] studied a strengthening method by utilizing steel plates on two-way square slabs subjected to punching loading. These steel plates were bonded in both sides (tension and compression) with epoxy and bolts in different patterns, numbers, and distributions. The results showed that the ultimate load increased by $56 \%-64 \%$. The author in [3] tested RC flat plates strengthened with strips of CFRP, which passed through holes in the slab around the column and were wrapped around to form closed stirrups. Different patterns were used depending on the number and position of the holes. The test results showed that the proposed method was successful in strengthening the slab-column connection and when the slabs were subjected to concentric and eccentric loads.

In the field of retrofitting damaged $\mathrm{RC}$ flat plates due to punching shear, authors in $[4,5]$ investigated experimentally the use of prestressed and non-prestressed shear bolts, which were inserted in the slabs around the column and were anchored in steel plates on the slab faces. They observed that the use of shear bolts led to an increment on the punching shear strength and can be considered efficient and applicable. Authors in [6] tested seven interior slab-column connections to evaluate the effectiveness of various rehabilitation techniques (CFRP stirrups, well anchored CFRP sheets, and square tube steel collars) on repairing seismic-damaged slab-column connections and improving their punching shear strength. The installation of the steel collars prevented punching shear failure under the application of simulated seismic displacements.

Authors in [7] conducted an experimental research on the strengthening of slab-column connection by bonded CFRP strips. The CFRP strips were fixed on the tension face of the slab in perpendicular or inclined orientation around the slabcolumn connection and were bonded by an epoxy adhesive at adjusted or offset at the column face. The test result showed increment in punching strength up to $29 \%$ for strengthened specimens in comparison with the reference slab. Also, the strengthened slab was much stiffer when the CFRP strips were near the column while the punching shear strength increased when the strips were offset from the column. Authors in [8] studied the load-deflection behavior and the load-carrying capacity of RC flat plates built on corner columns using the non-linear three-dimensional finite element software ANSYS. The obtained failure mechanism showed that the slabs failed near the columns due to the flexural punching mechanism resulting from local flexural yielding of the slab reinforcement around the column.

The effect of column rectangularity (aspect ratio) on the punching shear behavior is not dependent on the column crosssection dimensions only, and becomes more serious as the ratio of the minimum column dimension to the effective slab depth

Corresponding author: Ahmed Aziz Abdulhussein 
increases [9]. Authors in [10] outlined a simple theoretical method based on the yield line theory to predict the flexural capacity of a strengthened RC flat slab with unequal-leg steel angle plates. Adding fibers to the concrete made the flat plate fail in a more ductile mode, while the failure was sudden with brittle mode in slabs that contained no fibers [11-13].

In this research, punching shear strengthening of RC flat plates is investigated by using steel angle sections (steel collars) fixed in the column-slab connection region by epoxy and stud bolts in the column. One control specimen without strengthening and 5 strengthened specimens with steel collars of different thickness were experimentally tested. The analytical predictions of the punching shear capacity obtained with the use of the ABAQUS software were compared with the experimental results.

\section{TEST SPECIMENS}

The studied specimens in this paper were $6 \mathrm{RC}$ flat plates with dimensions of $1500 \times 1500 \times 100 \mathrm{~mm}$ with effective depth $\mathrm{d}=70 \mathrm{~mm}$, column with cross-section $150 \times 150 \mathrm{~mm}$, and height $200 \mathrm{~mm}$ located at the center of the slab. All specimens were tested under punching loading and were simply supported in the four sides over a span of $1400 \mathrm{~mm}$. Two meshes of flexural reinforcement were used in the specimens, $\phi 10$ at $75 \mathrm{~mm} \mathrm{c} / \mathrm{c}$ in the tension zone and $\phi 8$ at $150 \mathrm{~mm} \mathrm{c} / \mathrm{c}$ in the compression zone, whereas the yield strength of the reinforcements was 616 and $624 \mathrm{MPa}$ respectively. The compressive strength of the concrete cylinders was $30 \mathrm{MPa}$ and the column was reinforced with 4 $\phi 16 \mathrm{~mm}$ and $\phi 8 \mathrm{~mm}$ stirrups. One of these specimens was used as a control slab ( $\mathrm{S}_{0} /$ Reference), without any strengthening. The rest 5 flat plates, were strengthened with steel collars connected to the region of slab-column connection by epoxy and stud anchors. The yield strength of steel angles is 400, 400, 440,420 , and $375 \mathrm{MPa}$ for thicknesses of $4,5,6,8$, and $10 \mathrm{~mm}$ respectively and the stud anchors had yield strength of $520 \mathrm{Mpa}$. The details of the tested specimens are shown in Figure 1.

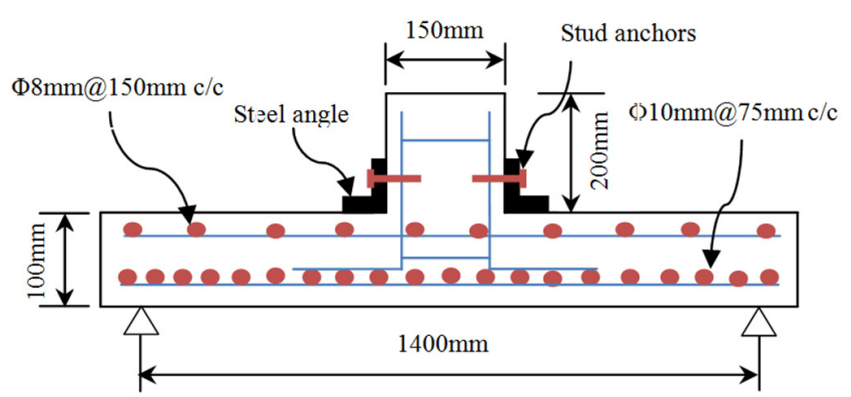

Fig. 1. Details of the tested specimens.

Variable thicknesses of steel collars were used in the 5 flat plates:

- $75 \times 75 \times 4 \mathrm{~mm}$ steel angle (S1/collar/75/4)

- $75 \times 75 \times 5 \mathrm{~mm}$ steel angle (S2/collar/75/5)

- $75 \times 75 \times 6 \mathrm{~mm}$ steel angle $(\mathrm{S} 3 /$ collar/75/6)
- $75 \times 75 \times 8 \mathrm{~mm}$ steel angle (S4/collar/75/8)

- $75 \times 75 \times 10 \mathrm{~mm}$ steel angle (S5/collar/75/10)

\section{TEST SETUP AND MEASUREMENTS}

The tests were carried out in the structural laboratory of the Department of Civil Engineering of the University of Baghdad. The specimens were setup on a simply supported steel frame in 4 edges and the load was applied concentric to the column stub (Figure 2). To record the vertical deflection, three Linear Variable Differential Transducers (LVDT) were used, the first one beneath the centre of the slab and the other two were located at the $1 / 3$ and $2 / 3$ of the distance between the centre of the slab and the support. To measure the strain in the reinforcements and steel collar, steel strain gages were placed in the tension reinforcements under the center of the column and near the inner edge of the steel angle. The strain in concrete was measured using concrete strain gauges attached to the top surface of the slab (compression face) and the bottom surface (tension face) at distance equal to $4 \mathrm{~d}$ from the face of the column (this paper was drawn from a $\mathrm{PhD}$ dissertation that had many specimens strengthened with large sizes of steel angles (e.g. $150 \times 150 \times 10 \mathrm{~mm})$ and the strain gauges were put in the same position to all specimens in order to make comparisons between the samples. For this reason the distance $4 \mathrm{~d}$ was used to avoid the location of strain gauge located on the leg of the steel angle). All instrumentations were connected to a computer by a data logger and the measurements were recorded with the Lab View 2018.

(a)

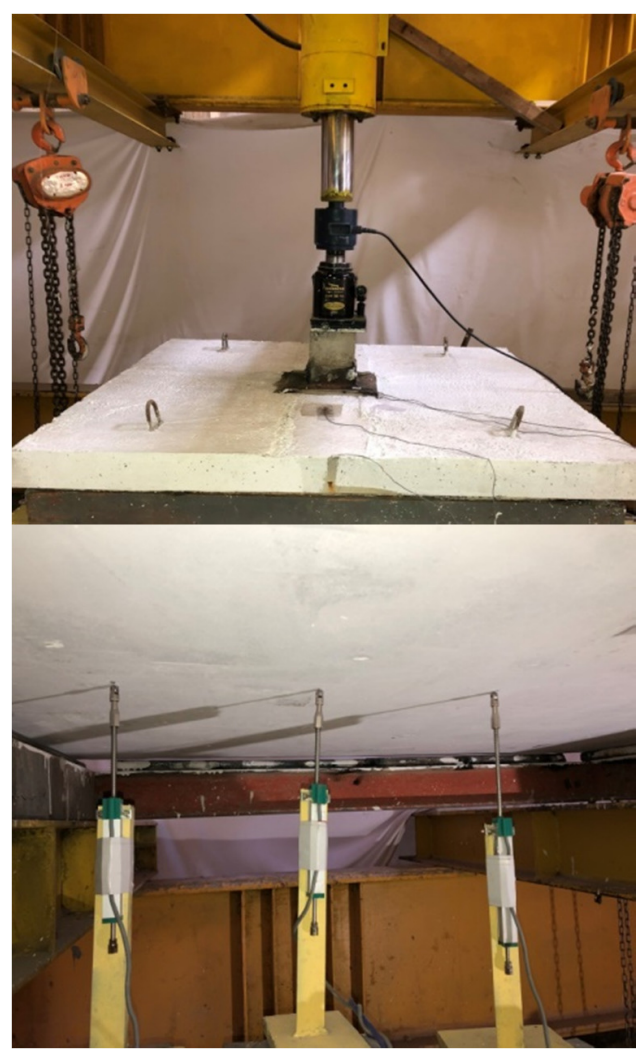

Fig. 2. (a) Test setup and (b) LVDTs distribution. 


\section{STRENGTHENING PROCEDURE}

The steps of strengthening the column-slab connection of $\mathrm{RC}$ flat plates using steel angle sections are:

- Form the steel angle as shown in Figure 3 by cutting one leg of steel angle with the right angle and the other leg cut with an angle of $45^{\circ}$.

- Roughen the region of concrete where the steel angle will be attached (the area of slab-column connection).

- Drill a hole on the column face in four sides using a hammer drill.

- Clean the steel angle pieces with sand paper.

- After cleaning the specific area from dust, insert Hilti stud anchor $\phi 10 \mathrm{~mm}$ (Figure 4) in the hole of the column and apply a two-part epoxy resin Sikadur 31 (Figure 5) on the concrete surface. Then attach the steel angles in the four sides of the column and tighten the studs which passed through the holes of the steel angles.

- Weld the pieces of steel angles together to be like a collar around the column.

The procedure of the strengthening mechanism is shown in Figure 6.

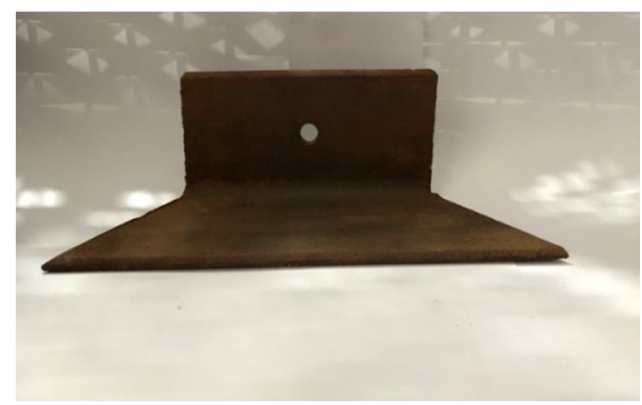

Fig. 3. A piece of steel angle.

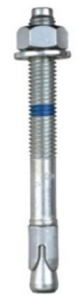

Fig. 4. Hilti stud anchor.

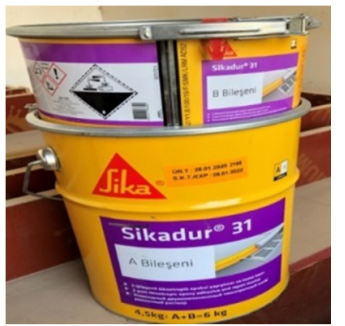

Fig. 5. Sikadur 31 .

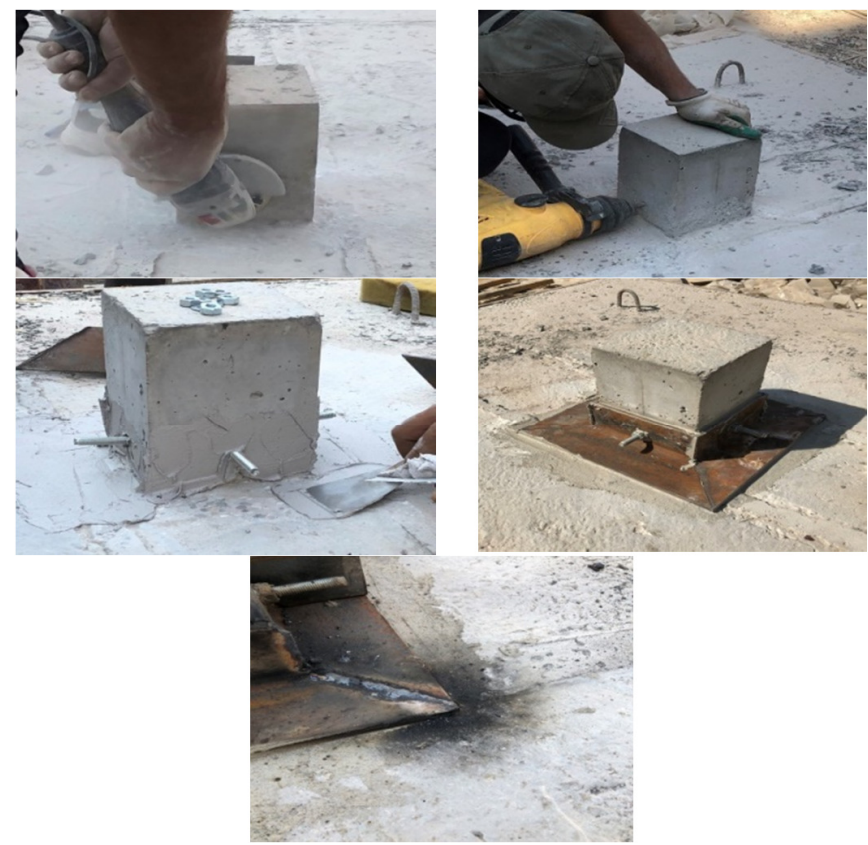

Fig. 6. The strengthening steps of column-slab connection.

\section{TEST RESULTS AND DISCUSSION}

\section{A. Load-Deflection Response}

Three LVDTs were used to measure the vertical deflections in (C), (a) and (2a). C represents the center of the slab and the a represents one third of the distance from the center to the support. Figure 7 showed that the load-deflection curves began as elastic and stiffer until first cracking. After that, the deflection increased rapidly and the stiffness decreased until the failure load was reached. In the reference specimen, the punching failure occurred suddenly but in strengthened specimens, before the collapse the crack number and the width of cracks increased giving alarm for failure. The ultimate load of the strengthened specimens increased with respect to the reference slab between $41 \%$ and $77 \%$ as the thickness of steel collars increased.

Table I shows the cracking and ultimate loads and the enhancement ratio of punching shear resistance due to the strengthening of the specimens by steel collars with variable steel angle thickness. The $\mathrm{P}_{\mathrm{cr}}$ of strengthening specimens were larger than unstrengthening slab.

TABLE I. RESULTS

\begin{tabular}{|c|c|c|c|c|c|c|}
\hline ID & $\begin{array}{c}\text { Collar } \\
\text { thickness } \\
(\mathbf{m m})\end{array}$ & $\begin{array}{c}\mathbf{P}_{\mathbf{c r}} \\
\mathbf{( k N )}\end{array}$ & $\begin{array}{c}\Delta_{\mathbf{c r}} \\
(\mathbf{m m})\end{array}$ & $\mathbf{P}_{\mathbf{u}} \mathbf{( k N )}$ & $\begin{array}{c}\Delta_{\mathbf{u}} \\
(\mathbf{m m})\end{array}$ & $\begin{array}{c}\text { Enhancement } \\
\text { ratio } \mathbf{P}_{\mathbf{u}}(\mathbf{\%})\end{array}$ \\
\hline $\mathrm{S}_{0}$ & $\mathrm{R}$ & 30 & 1.94 & 161 & 23.8 & $\mathrm{R}$ \\
\hline $\mathrm{S}_{1}$ & 4 & 38 & 2.7 & 227 & 26.33 & 41 \\
\hline $\mathrm{S}_{2}$ & 5 & 37 & 2.1 & 240 & 26.4 & 49 \\
\hline $\mathrm{S}_{3}$ & 6 & 38 & 2.9 & 251 & 29.8 & 56 \\
\hline $\mathrm{S}_{4}$ & 8 & 40 & 5.1 & 262 & 35.8 & 62.7 \\
\hline $\mathrm{S}_{5}$ & 10 & 40 & 4.8 & 285 & 40.5 & 77 \\
\hline
\end{tabular}


(a)

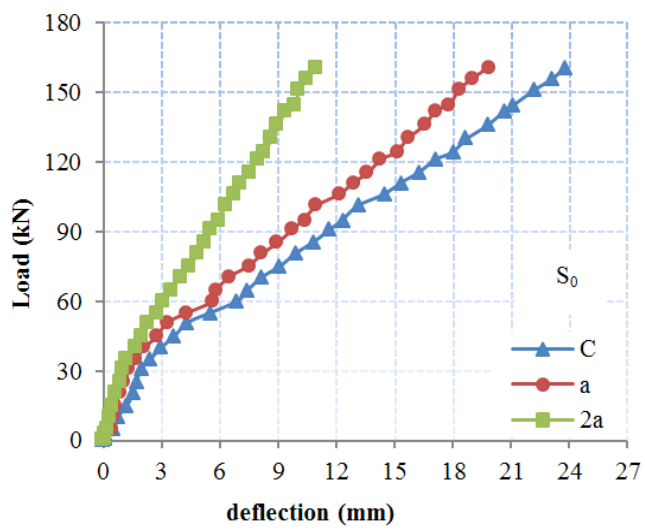

(b)

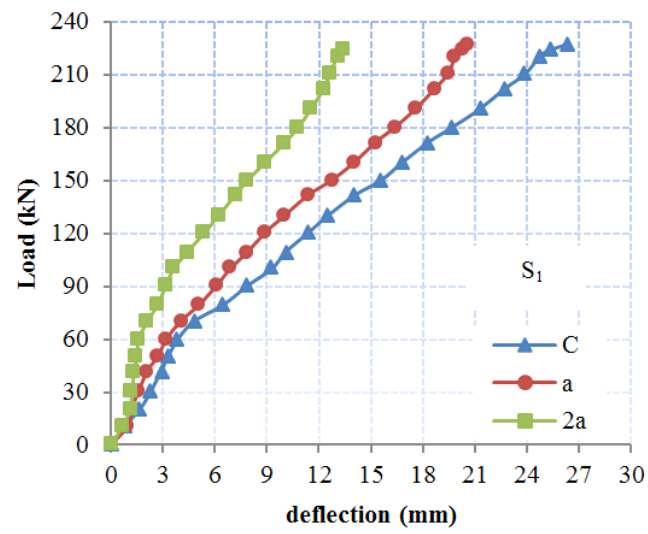

(c)

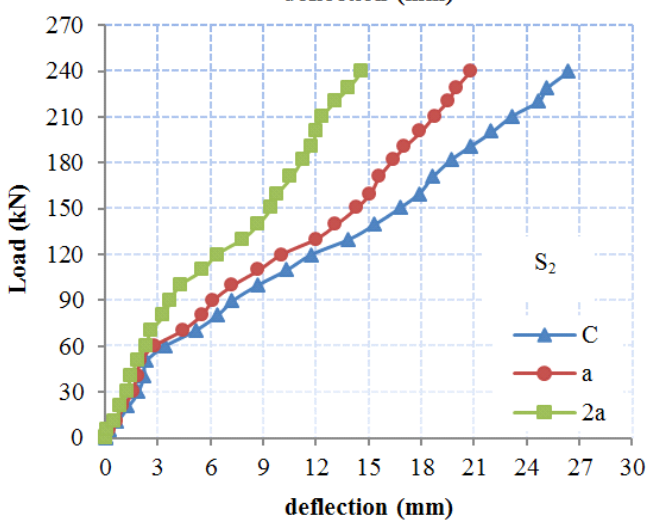

(d)

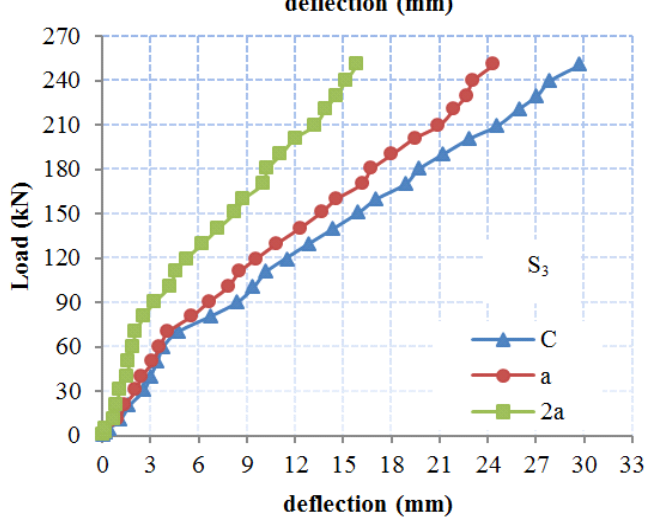

(e)

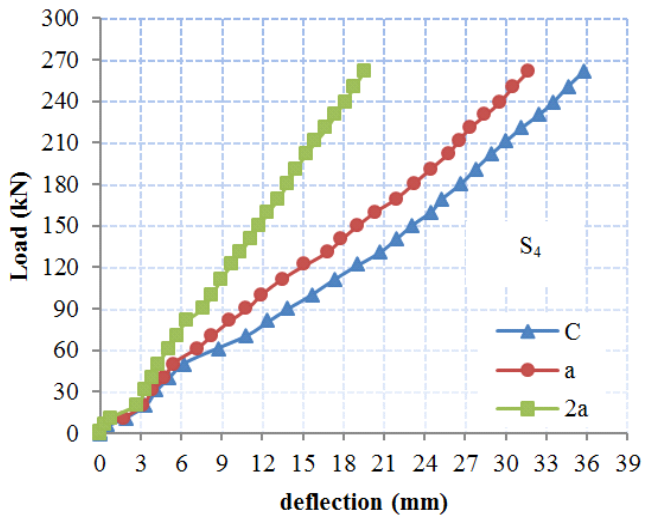

(f)

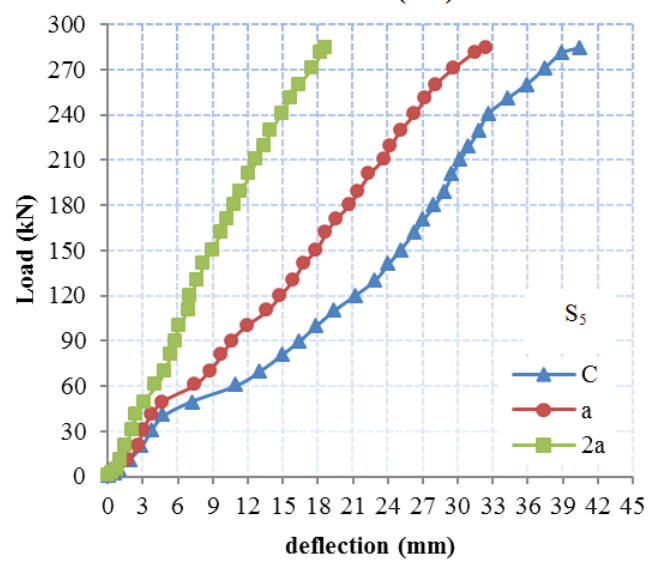

Fig. 7. Load-deflection relationship of the tested specimens.

\section{B. Strain in Flexural Reinforcements}

The strain was measured at the maximum moment under the center of the column to observe when the reinforcement reached yielding. The yield strain of tensile steel bars was equal to 0.0031 . Figure 8 shows the load-strain curves in flexural reinforcements for the reference slab and the strengthened specimens.

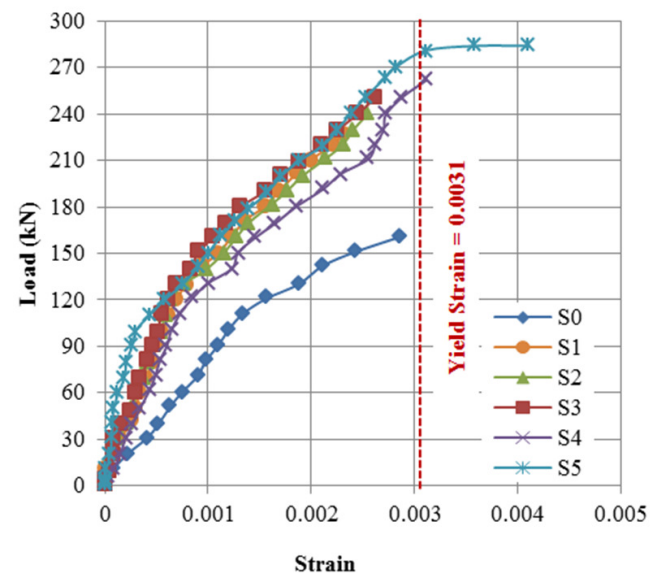

Fig. 8. Load-reinforcement strain of the tested specimens.

It was noticed that the specimens $\mathrm{S}_{0}, \mathrm{~S}_{1}, \mathrm{~S}_{2}$, and $\mathrm{S}_{3}$ failed in pure punching shear because the failure occurred before the 
reinforcement bars reached yield, but the mode of failure of $\mathrm{S}_{4}$ and $\mathrm{S}_{5}$ specimens combined flexural and punching shear, where the strains in the reinforcement exceeded the yielding limit before failure. The strengthened specimens showed enhancement in the values of strain, which decreased corresponding to the reference slab $\left(\mathrm{S}_{0}\right)$, due to the presence of the steel collars, which increased the stiffness of the specimens. Increasing the thickness of steel collars led to decrease in the strain values.

\section{Compressive and Tensile Strains in Concrete}

To measure the compressive and tensile strains of concrete, two strain gauges were fixed on the top and bottom concrete surfaces of the flat plate specimens at a distance equal to (4d) from the face of the column. Figure 9 shows the results of loadstrain relationship for the reference specimen and the five specimens with different thicknesses of steel collars. The relationships show that the values of tensile strains were higher than compressive strains in all tested slabs, because concrete is weak against tension, which makes the neutral axis move toward the compression zone of concrete. The compressive strains in the strengthened slabs were greater than that in the reference slab at the same level of loading due to the use of steel collars. When the thickness of steel collar increased, the compressive strain increased. On the other hand, the tensile strains in strengthened specimens decreased with respect to the reference specimen at the same level of loading. This gave an indication of enhancement in tensile strain because the strengthened specimens became stiffer than the reference slab.

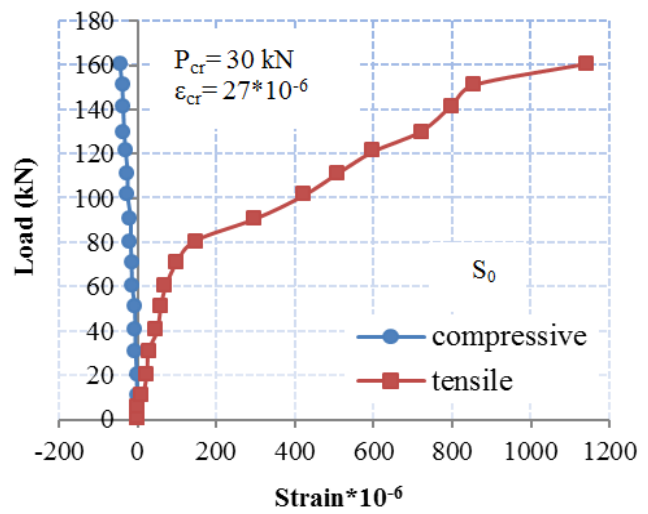

(b)

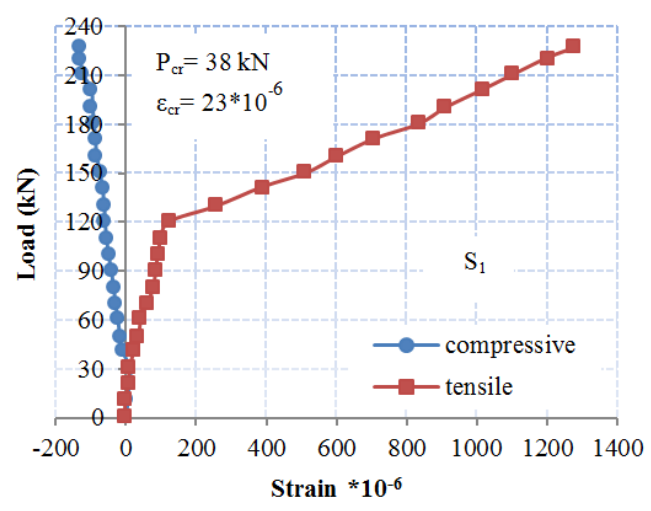

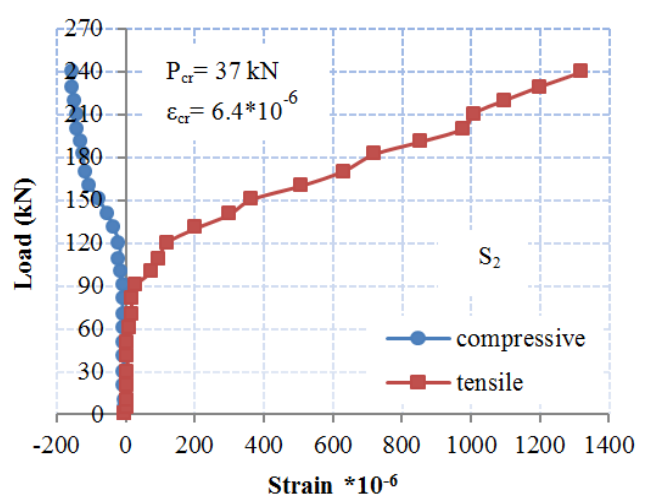
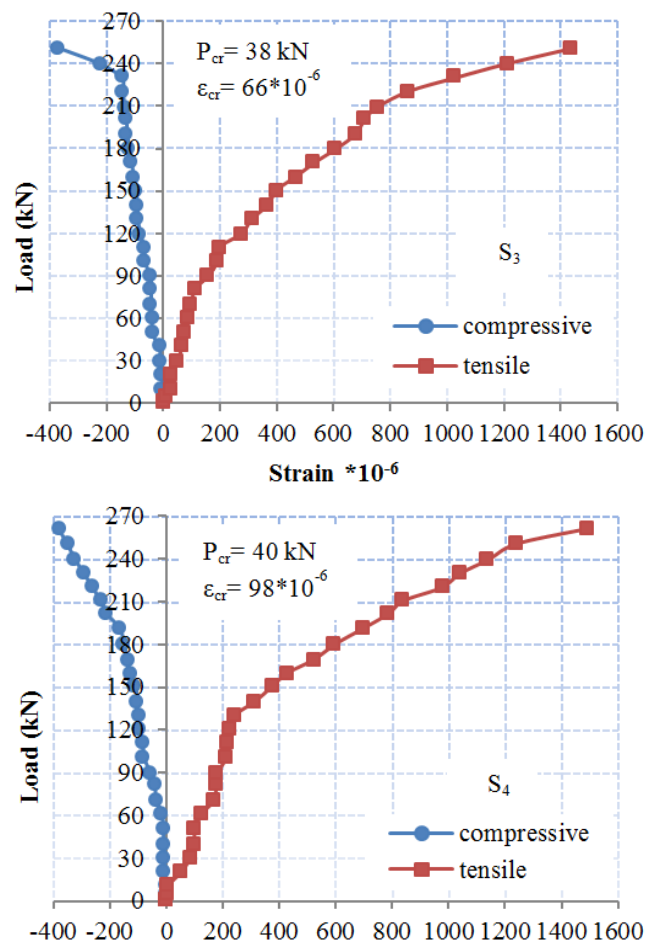
Strain $* 10^{-6}$

(f)

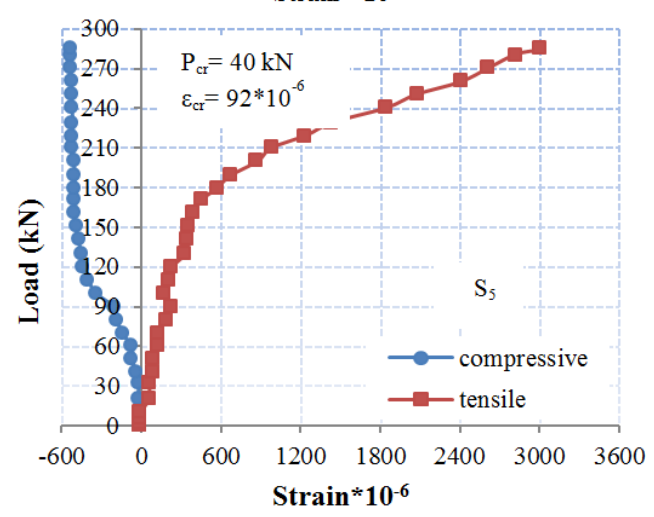

Fig. 9. Load-compressive and tensile strain in the tested specimens.

\section{Strain in the Steel Collars}

When failure occurred during the experimental tests of strengthened specimens, no deformation in the steel collars was observed and the strain recorded small values due to the high 
stiffness of steel angles due to the thickness of the steel section $(\leq 4 \mathrm{~mm})$. Also, no separation of the steel collars from the concrete was observed. The steel collar and the column penetrate the slab as one piece, due to the use of proper epoxy.

\section{FINITE ELEMENT MODELING}

Finite element analysis with the ABAQUS software was conducted to simulate the 6 flat plate specimens. Only one quarter was modeled due to the double symmetry of the flat plate specimens. Concrete slab was modeled as solid 3D-8 node brick elements (C3D8R) with reduced integration (Figure 10(a)). Truss elements with two nodded linear elements (T3D2) were used to model the steel reinforcements (Figure 10(b)) and the embedded method was used to model the interaction between reinforcements and concrete, assuming perfect bond between them.

(a)

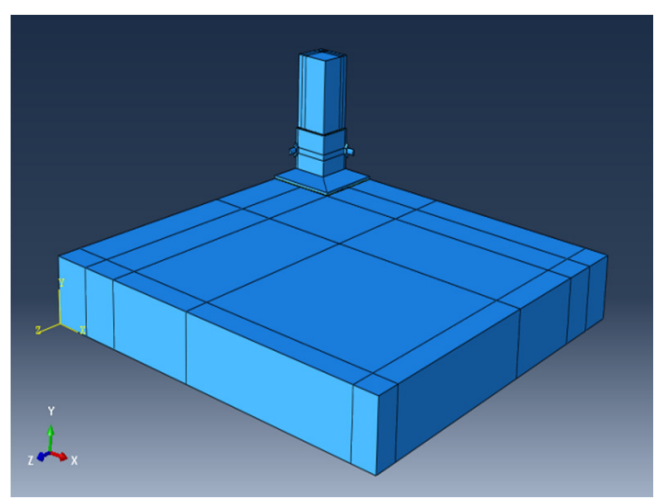

(b)

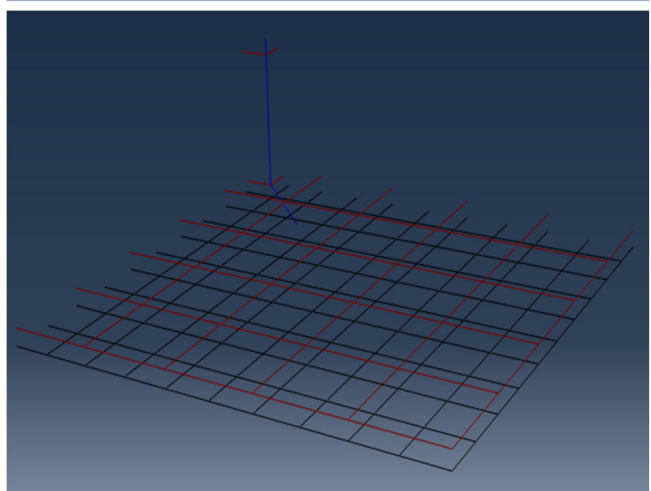

(c)

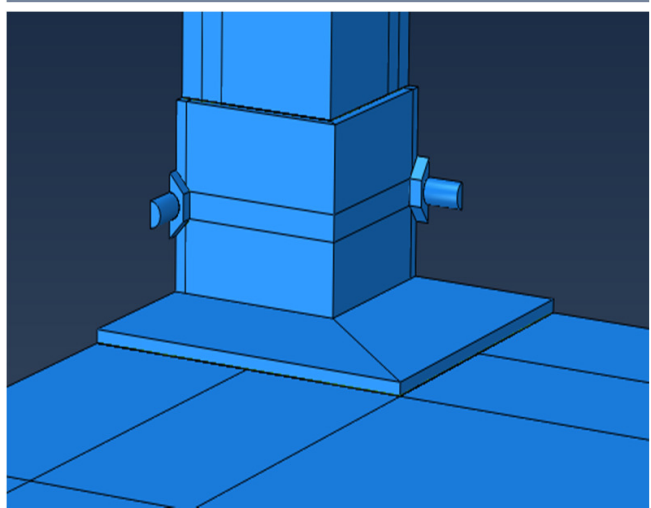

(d)

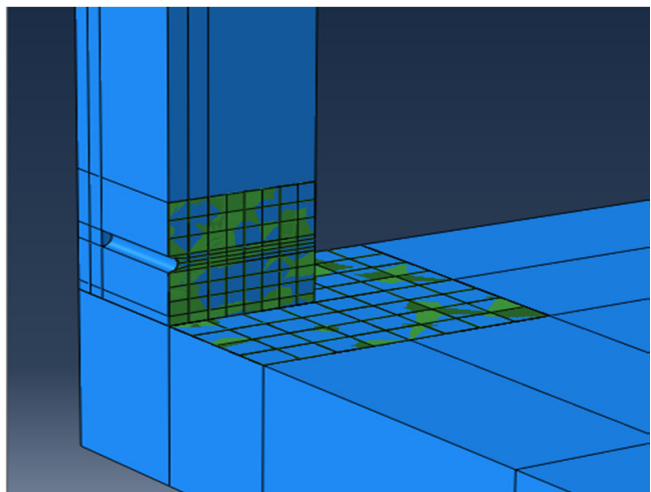

(e)

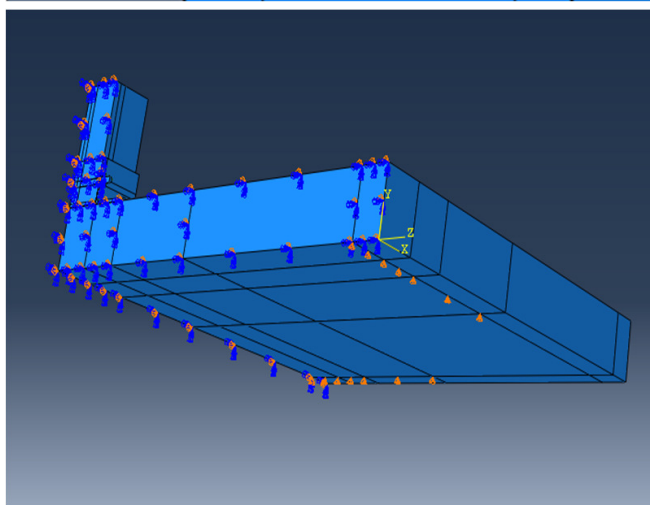

Fig. 10. Simulation of strengthening flat-plate specimens by ABAQUS. (a) Geometry of concrete flat plate, (b) modeling of reinforcements, (c) steel collar and stud anchor, (d) epoxy, (e) boundary conditions and supports.

The steel collar and stud anchor were modeled as C3D8R solid elements (Figure 10(c)) and the epoxy was simulated as COH3D8 8-node three dimensional cohesive elements (Figure 10(d)) and a tie constraint modeled the contact between the steel collar and the concrete. The stud anchors were installed in columns by drilled holes and contact between them by the tie constraint. The boundary conditions and supports are shown in Figure 10(e) which simulates the supports as restrained at the bottom of slab in the $y$ - direction and lets the corners of slab free to lift.

\section{A. Load-Deflection Relationship}

Figure 11 shows the comparison between the experimental results and the numerical analysis of load-deflection curves for the reference and the strengthened specimens. A good agreement is observed. The difference between the experimental and the ABAQUS results for ultimate load ranges between $10.8 \%$ and $2.6 \%$.

\section{B. Crack Pattern}

The first crack starts near the edge of the column in the tension side of concrete with longitudinal form. The first cracking is followed by many longitudinal cracks forming parallel to the flexural bars. After increasing the load, transverse cracks began to appear and connect to the longitudinal cracks. Also, radial cracks formed from the center of the slab reached the corners and the edges. At the collapse load, shear cracks of irregular round shape were formed around the bottom of the column in the tension side. 
(a)

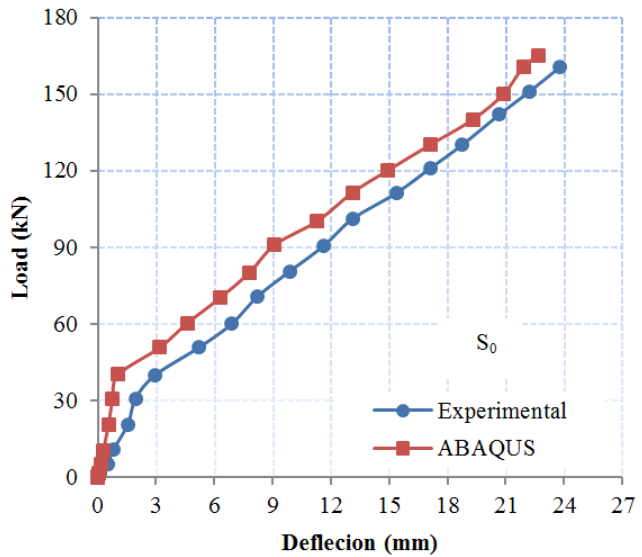

(b)

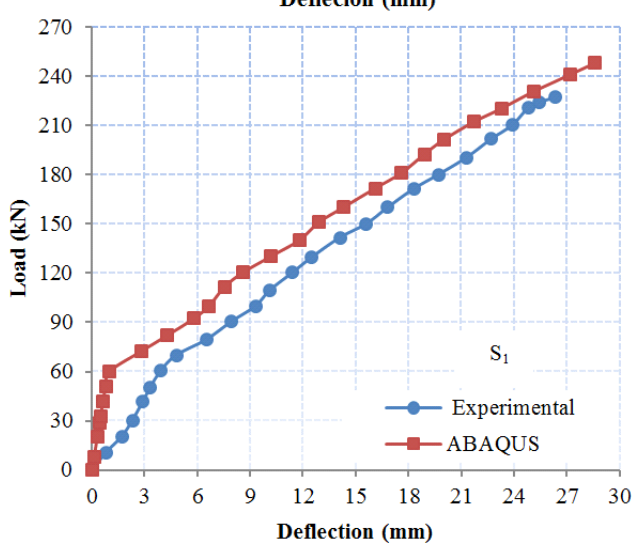

(c)

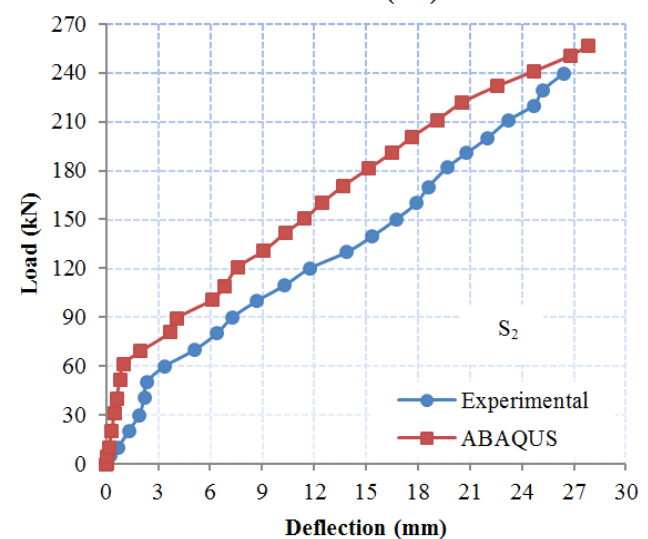

(d)

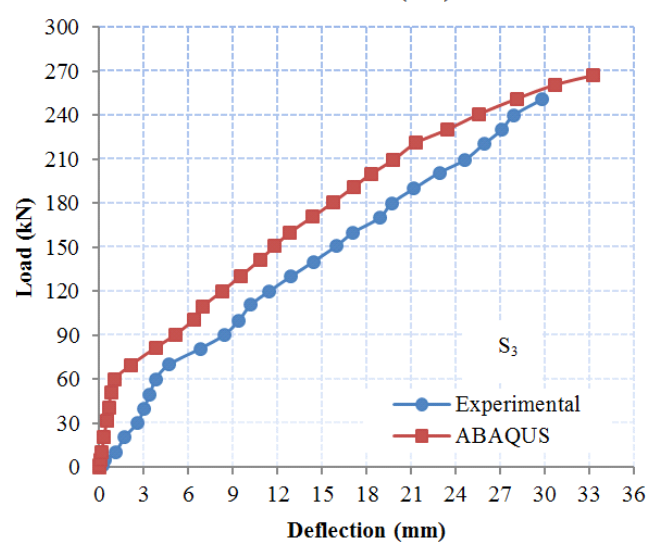

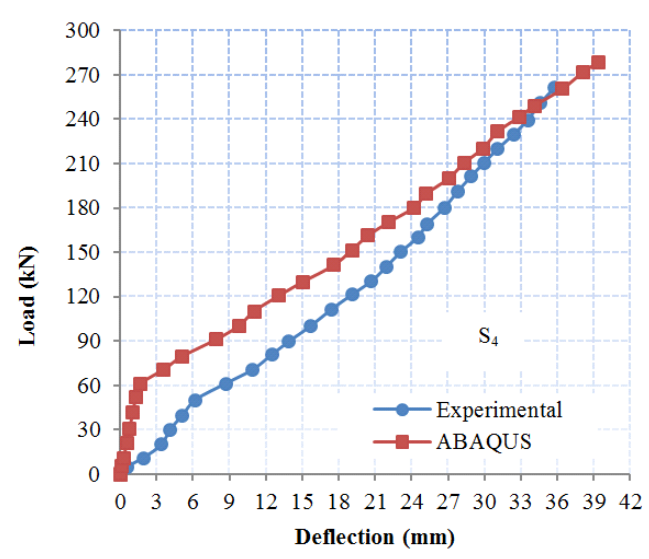

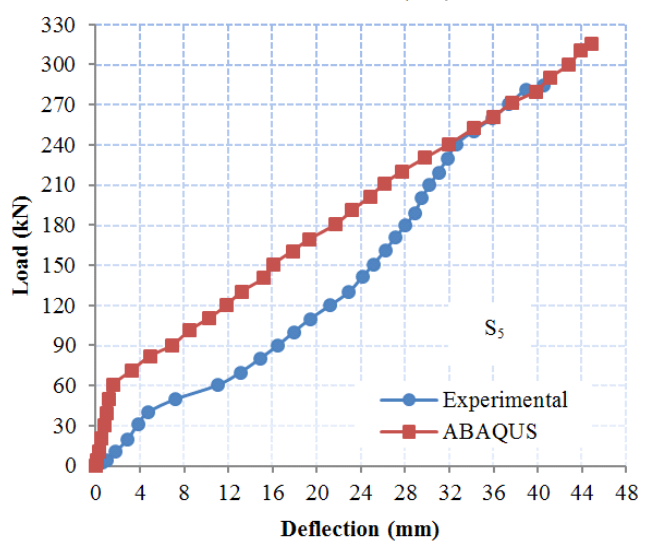

Fig. 11. Experimental and ABAQUS load-deflection curves.
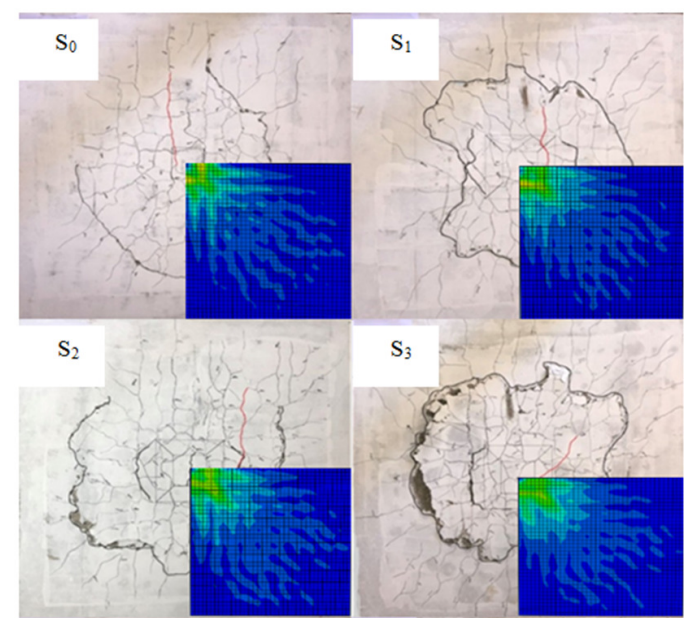

$\mathrm{S}_{3}$

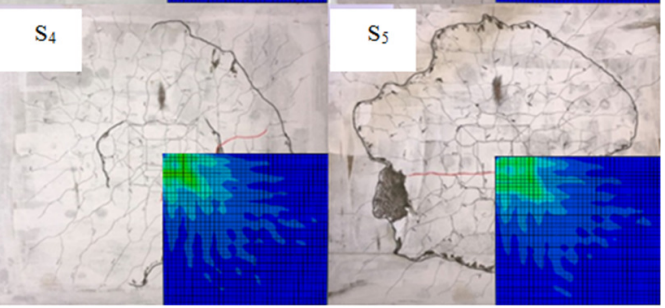

Fig. 12. Comparison between the experimental and the analytical crack pattern. 
In the strengthened specimens, the numbers of cracks was more than the reference slab because the load reached higher values. The perimeter of the failure area was increased at $\mathrm{S}_{4}$ and $\mathrm{S}_{5}$ which have maximum values of punching shear strength. Figure 12 illustrates the comparisons between the crack pattern of the experiments and the numerical analysis in ABAQUS.

\section{CONCLUSIONS}

- The punching shear resistance of strengthened specimens was enhanced with respect to the unstrengthened slab.

- The punching shear resistance of strengthened specimens increased with respect to the reference slab. The increment ranged between $41 \%$ and $77 \%$, and was bigger when the thickness of steel collars increased.

- The steel collars increase the perimeter of failure zone therefore the shear strength increases.

- The value of cracking load increased in strengthened slabs due to the presence of the steel collar, which increased the stiffness of the region around the column in which the first crack began to appear.

- The values of reinforcement strain decreased in the strengthened specimens due to the presence of the steel collars which increased the stiffness of the specimens.

- The strengthened specimens showed enhancement in tensile concrete strain.

- The strengthened specimens $\mathrm{S}_{4}$ and $\mathrm{S}_{5}$ failed in a combined punching-flexural mode. The steel collar strengthening technique has effectively turned the final mode of failure from punching shear to flexural and punching shear mechanism outside the strengthened zone.

- The technique of strengthening by steel collars was easy, effective, and fast to implement with respect to previous studies that used steel sections.

- The collapse in strengthened specimens did not occur suddenly which gave alarm by the increased number and width of cracks.

- The results of the comparison between the experimental and the numerical load-deflection curves and crack patterns for the reference and the strengthened specimens were in a good agreement.

\section{ACKNOWLEDGMENT}

The authors would like to thank the Department of Civil Engineering at the University of Baghdad for their support.

\section{REFERENCES}

[1] A. Ghali, M. A. Sargious, and A. Huizer, "Vertical Prestressing of Flat Plates Around Columns," Shear in Reinforced Concrete, vol. 42, pp. 905-920, Jan. 1974, https://doi.org/10.14359/17314.

[2] U. Ebead and H. Marzouk, "Strengthening of two-way slabs using steel plates," ACI Structural Journal, vol. 99, no. 1, Jan. 2002.

[3] B. Binici and O. Bayrak, "Punching Shear Strengthening of Reinforced Concrete Flat Plates Using Carbon Fiber Reinforced Polymers," Journal of Structural Engineering, vol. 129, no. 9, pp. 1173-1182, Sep. 2003, https://doi.org/10.1061/(ASCE)0733-9445(2003)129:9(1173).

[4] M. M. G. Inácio, A. Pinho Ramos, and D. M. V. Faria, "Strengthening of flat slabs with transverse reinforcement by introduction of steel bolts using different anchorage approaches," Engineering Structures, vol. 44, pp. 63-77, Nov. 2012, https://doi.org/10.1016/j.engstruct.2012.05.043.

[5] H. S. Askar, "Repair of R/C flat plates failing in punching by vertical studs," Alexandria Engineering Journal, vol. 54, no. 3, pp. 541-550, Sep. 2015, https://doi.org/10.1016/j.aej.2015.03.033.

[6] Widianto, O. Bayrak, J. O. Jirsa, and Y. Tian, "Seismic Rehabilitation of Slab-Column Connections," ACI Structural Journal, vol. 107, no. 2, pp. 237-247, Mar. 2010, https://doi.org/10.14359/51663540.

[7] K. Soudki, A. K. El-Sayed, and T. Vanzwol, "Strengthening of concrete slab-column connections using CFRP strips," Journal of King Saud University - Engineering Sciences, vol. 24, no. 1, pp. 25-33, Jan. 2012, https://doi.org/10.1016/j.jksues.2011.07.001.

[8] A. Hameed, H. Husain, and M. Al-Sherrawi, "Analysis of Corner Column-Slab Connections in Concrete Flat Plates," East African Scholars Journal of Engineering and Computer Sciences, vol. 2, no. 1, pp. 37-46, Jan. 2019.

[9] G. J. Milligan, M. A. Polak, and C. Zurell, "Finite element analysis of punching shear behaviour of concrete slabs supported on rectangular columns," Engineering Structures, vol. 224, p. 111189, Dec. 2020, https://doi.org/10.1016/j.engstruct.2020.111189.

[10] H. R. Taresh, M. Y. M. Yatim, and M. R. Azmi, "Punching shear behaviour of interior slab-column connections strengthened by steel angle plates," Engineering Structures, vol. 238, p. 112246, Jul. 2021, https://doi.org/10.1016/j.engstruct.2021.112246.

[11] A. N. Dalaf and S. D. Mohammed, "The Impact of Hybrid Fibers on Punching Shear Strength of Concrete Flat Plates Exposed to Fire," Engineering, Technology \& Applied Science Research, vol. 11, no. 4, pp. 7452-7457, Aug. 2021, https://doi.org/10.48084/etasr.4314.

[12] A. S. Mahdi and S. D. Mohammed, "Experimental and Numerical Analysis of Bubbles Distribution Influence in BubbleDeck Slab under Harmonic Load Effect," Engineering, Technology \& Applied Science Research, vol. 11, no. 1, pp. 6645-6649, Feb. 2021, https://doi.org/ 10.48084/etasr.3963.

[13] B. Gebretsadik, K. Jadidi, V. Farhangi, and M. Karakouzian, "Application of Ultrasonic Measurements for the Evaluation of Steel Fiber Reinforced Concrete," Engineering, Technology \& Applied Science Research, vol. 11, no. 1, pp. 6662-6667, Feb. 2021, https://doi.org/10.48084/etasr.3915. 